\title{
In Quest of SME-Conducive Policy Formulation*
}

\author{
J. Hanns Pichler
}

\begin{abstract}
A B S T R A C T
Objective: The article focuses on the role of SMEs in the national, regional and global environment. The main objective of the article is to present the economic and social importance of SMEs in the context of policy formulation for their support and development.

Research Design \& Methods: The article reviews the theoretical and empirical literature on SMEs and their role in business environment. Then the paper develops a set of questions and propositions to guide future research and policy.
\end{abstract}

Findings: The article describes a significant role of SMEs for job creation and economic dynamics. Over the economic considerations, relevance of SMEs is to be viewed also from a more broadly based socio - economic perspective; that is, SMEs being seen as a driving force of structural change on the one hand, and as stabilising factor for safeguarding a given economic setting with its institutional framework in the dynamics of change on the other.

Implications \& Recommendations: The complexity and dynamics of market processes determine the diversification of SME policy. Identifying contemporary challenges faced by SMEs are 'building stones' for specific policy formulation in the future.

Contribution \& Value Added: The study highlights the need to deepen the understanding of the current role of SMEs for the labour market and welfare. What is more, the SMEs policy should be articulated more offensively as a key component of the economic policy in general.

\begin{tabular}{ll}
\hline Article type: & policy paper \\
Keywords: & SMEs; policy formulation; environment \\
JEL codes: & D02, D04, L21
\end{tabular}

Received: 31 March 2014 Revised: 27 January 2018 Accepted: 2 February 2018

\footnotetext{
* The paper was presented during the V4 Conference on 'International Entrepreneurship and Internationalization of firms in V4 Countries' organised by the Centre of Strategic and International Entrepreneurship, Cracow University of Economics in Krakow (Poland) on April 3, 2014. This article (policy paper) is its written and extended version. This article is the modified and updated version of the publication (Pichler, 2015).
}

\section{Suggested citation:}

Pichler, J.H. (2018). In Quest of SME-Conducive Policy Formulation. Entrepreneurial Business and Economics Review, 6(1), 105-113. https://doi.org/10.15678/EBER.2018.060106 


\begin{abstract}
'Why are SMEs so important ... Because high employment growth in SMEs in the last decades has prevented unemployment rising ... in the European Economic Area'.

The European Observatory for SMEs
\end{abstract}

\title{
INTRODUCTION
}

The topic itself raises an ever challenging question: that is, about the role and significance, if not to say the 'survival' of small and medium-sized enterprises (SMEs) and related structures within an environment of forces which - particularly in the sphere of industry - at first sight tend to favour the 'big' rather than the 'small'. This at the same time points at the underlying aspects and challenges of broader socio-economic and structural dimensions with a concomitant need for the appropriate formulation of more differentiated and specifically designed business policies in general.

Such challenges and related problems today are to be seen from an inseparably intertwined and multipronged point of view:

- From a more and more international view, not the least as a strategic ingredient of development to be the recognised perception of the role and exposure of SMEs in their sectorrelated structural significance nationally, regionally and nowadays, in fact, globally.

- Then, from a closer to the skin view of developments related to on-going restructuring in our European and - when speaking of SMEs - in many ways regionally unique business environment.

- Finally, under overriding socio-economic and systems-related aspects of a more comprehensive SME-specific policy formulation.

\section{Global Environment}

Globally, the evidence of new and growing recognition of the role of SMEs is witnessed by quite profound reorientation in development policy over the last decades with a distinct change in strategies toward fostering sector-related diversification for more balanced long-term growth and economic welfare under generally sustainable conditions.

When speaking of strategies, there is today an ever-growing awareness worldwide of the role of SMEs both as a factor of sustaining economic stability and simply as an indispensable catalyst for fostering economic dynamics and welfare. The experience and recognition thereof has triggered more broadly based rethinking and change in the outlook, quite in contrast still to post-war decades, when sustained economic buoyancy, business dynamics and growth to a large extent tended to blur the need for any more subtle structural considerations. Yet, the underlying economic realities and the very characteristics of any SME structured business environment, finally were not to be indefinitely neglected with impunity.

Altogether - and not the least from the European angle - this has largely disproved more orthodox and seemingly ill-conceived notions of any inherent superiority of the 'big' versus the 'small', thus recognising the specific role of SMEs in the context of a more subtle and diversified approach towards 'structural development'. 


\section{Specifics of the European Environment}

Narrowing our focus geographically and taking a closer look, e.g., at the specificity of the European business environment, a unique, richly structured and indeed highly diversified SME 'landscape' emerges. A landscape with manifold facets as vividly illustrated again and again by the 'European Observatory for SMEs'. Thus, it is shown that SMEs (defined as up to 250 employees) within the 'European Space' in a broader sense number somewhere close to 20 million units, as against only about 40.000 , or just $0.2 \%$ of larger firms (with more than 250 employees); this makes up an average of some 50 (non-primary) business establishments per 1000 inhabitants! Furthermore, these millions of smaller - in a considerable part craft-dominated micro-enterprises - over the past years have continuously tended to outperform larger enterprises in terms of job creation. This at the same time demonstrates that without such relatively high employment growth and intensity on the part of SMEs, the European unemployment syndrome would have been even more pronounced!

While illustrating thereby the economic and social importance of SMEs in the European context, this further implies - as stated in the 'Observatory' mentioned - that over the years an estimated 1.5 million Europeans annually decide to start a business of their own; and this way, over half a decade or so, the number of (mostly small to very small) enterprises has increased by about $9 \%$, while the EU population has grown by only about $2 \%$.

In the country-specific terms, it is quite typical too when, e.g., in Austria - and similarly in Germany, in Switzerland and elsewhere - nearly $99 \%$ of all non-agricultural business establishments have less than one hundred employees; and of those again close to $90 \%$ have less than 10 , and less than $2 \% 100$ or above. Moreover, in terms of sustaining employment, the SME sector on the whole - due to its flexibility and adaptability, in the period of profound industrial restructuring, was by and large able to absorb, and thereby compensate for, on-going layoffs in the larger public sector-dominated industries to the tune of some 80.000 employees (or nearly 3\% of Austria's total workforce).

While recognising such proven strength not only structurally but also as providing a certain measure of resilience against business cycle volatilities, one might take note of the fact that it is exactly in the sphere of SMEs as well where-due to their more immediate socio-economic exposure - conflicts of interest (not free at times from certain partisanship) do arise and are being fought out; conflicts implying both positive and negative repercussions as to the sector-related policy formulation with concomitant institutional implications. Frequently, this indeed resembles the arena where in essentially market-based systems 'the very action' is; where policy challenges and demands are being articulated in ever so numerous nuances and facets.

The sheer existence and sustained survival of SME structures with their complexities as mirroring the reality of economic life itself, visibly contradicts erstwhile widely spread 'prophecies' of the ultimate demise of small businesses as a predicament under both 'classical' and, of course, Marxist doctrines. Historical evidence and today's systemic transformation processes in formerly Soviet-dominated Central and Eastern Europe clearly point to the opposite; the very essence of the restructuring going on there more than ever calls for speedy creation or revival of sound and diversified SME structures as simply an indispensable ingredient for any sustained recovery as one of the strategically most challenging issues. 
All too easy at times, as it seems, the inherent wealth and diversity of typically SME structured business scenarios are merely taken for granted; this perhaps too, because we are somehow used to the fact that SMEs have always been or simply ought to be there anyway. Yet, for any more conscious policy considerations this, in fact, is not so self-evident; it rather does call for continued awareness to assure that underlying resilience and adjustment capabilities are constantly safeguarded.

Such adjustment capabilities to changing business conditions and, at times, volatile cyclical movements, quite typically are characterised also by structural permeability both upwards and downwards: that is to say, by way of adjusting - and in today's scenario the more relevant - to forces of regional (or even global) integration with implicit restructuring of business sizes. Such restructuring, by its very nature, is not to be interpreted one-sidedly as simply a tendency towards 'concentration' only; rather, and more objectively so, it is equally to be seen as a process of opening up opportunities also 'downstream' in terms of structural deepening as markets and, in particular, the size of markets change.

The insights of modern industrial economics give credence to such complexities in the course of structural adjustment with, in part, new evidence as to criteria of 'optimal' business sizes being induced, e.g., by technological developments. Thereby, placing emphasis not so much on economies of 'scale'; but rather more on elements such as SME-specific diversification or differentiation rendering classical returns to 'scale' no longer so valid an argument as against economies of 'scope'. More pointedly still, it implies conscious recognition of such complexities as, e.g., regional specifics and market differentiation, locational spread, including relative density of businesses relating to given demand and supply patterns, with implications again for product/market orientation and diversification of size structures as relevant for both forward and backward linkages of respective business activities.

Any SME policy addressing such complexities finally has to do with what one might subsume under contributing to 'quality of life' and to conditions of welfare in a broader sense. Endowment with diversified business structures and, thereby, with enhanced economic opportunities, productive capacities and increased potential for catering to differentiated, individualised patterns of demand finally needs to be judged with a view to such qualitative aspects (a study to this effect conducted in Austria, for example, depicts regional differences in relative SME density between 40 and 80 per 1000 inhabitants as clearly correlating with respectively higher or lower levels of economic welfare, incomes and purchasing power.)

\section{Socio-Economic Dimension of the Environment}

Over and above mere economic considerations, relevance of SMEs, finally, is to be viewed also from a more broadly based socio-economic point of view; that is, SMEs being seen as a driving force of structural change on the one hand, and as a stabilising factor for safeguarding a given economic setting with its institutional framework in the dynamics of change on the other hand.

For any freedom- and as such market-oriented socio-economic order as a form of life, this unequivocally implies commitment to entrepreneurial initiative, to guarantee both free and autonomous pursuit of business opportunities; furthermore, it implies commitment to market criteria of performance with quite a legitimate claim for an adequate return under due consideration of social (including environmental) responsibility in the conduct of business as such. It also means that any such policy inescapably becomes part and 
parcel of shaping socio-economic conditions as a conducive framework wherein SMEs, with their diversified structures and patterns of performance, can thrive as indispensable for guaranteeing and sustaining welfare conditions for society as a whole - constituting undoubtedly a policy challenge at any time anywhere.

Such a policy ought not to shy away from the very 'nitty gritty', either: such as, e.g., avoiding to burden SMEs in a discriminatory manner with unremunerated administrative tasks by public authorities. A study to that effect in Germany demonstrates that the relative impact in terms of cost and manpower to be allocated proves up to 22 times (!) and, thus, quite disproportionately higher for SMEs as compared to larger enterprises. In a somewhat more sarcastic vain, but pointing essentially in the same direction, the US Small Business Administration some time back undertook to illustrate that roughly 10 million businesses under its constituency got inundated yearly by well over 300 million forms with up to one billion pages containing more than 7 billion questions; altogether entailing unremunerated costs averaging some 3000 USD.- or more per firm. Gracefully perhaps, a similar EU related assessment has not, as yet, been carried out!

If on the other hand - as it is often quite 'liberally' claimed - it is to be recognised that SMEs indeed represent the mainstay or very 'trade mark' of any market oriented economy; and if it is true further, as variously being claimed, that - due simply to the existence of more diversified SME structures - economies over and over again were able to prove their adaptive capabilities for both overcoming even severe policy mistakes and at the same time taking on new challenges, then it would be only consequential for any related policy to attain a certain measure of 'natural' legitimacy of its own.

\section{CONCLUSIONS}

Upon closer scrutiny of such pronouncements and arguments though, one might be left wondering whether this kind of demands and recommendations do not remain pretty much on the surface and, thus, tend to fall way short of recognising more profound issues involved; whether not - if argued from a systems-related point of view indeed more deeply probing questions as to the really crucial 'building stones' of any SME-specific policy were to be addressed, as e.g.:

- Questioning, with a view not the least to prevailing structures, whether 'classically' defined strategies of blatant 'marketeering' indeed make for adequate and sensitive enough a policy taking proper cognisance of underlying diversities and complexities?

- Questioning further whether sheer prevalence of SME diversification with related institutional structures not might rather call for an equally differentiated policy; a policy which within an essentially market based framework - just as well allows for appropriate multiplicity of cooperative (corporatist) or in various ways subsidiary forms of business organisation and relationships as a kind of 'natural' ingredient, if not enrichment of any economic system pointing beyond simple supply and demand mechanisms at the very micro level?

- Considering lastly, and without wanting to seem 'heretical', whether not - and possibly quite legitimately so - to foster and thereby acknowledge intermediate forms of business associations at the meso level as a simply inescapable feature of institutionalisation for any sound SME policy recognising, in principle: 
o for one, that competition as a coordinating 'mechanism' via markets constitutes only one - but not the only one - criterion or instrument governing business conduct and, depending on given sectoral or structural conditions, not necessarily is to take centre stage; or putting it more bluntly: that the acceptance of an essentially competitive, market-oriented economic order for SMEs equally requires an appropriate framework of institutions going along with,

o furthermore, that the cognisance of such specifics with implicit forms of institutionalisation may prove more conducive to SME-related business conduct than any undifferentiated plea for cut-throat competition at micro level, by emphasising and bringing to bear economies of 'scope' rather than of 'scale'; or in short: considering SMEs not merely as 'beautiful', but also as being 'efficient' in a more comprehensive sector-specific understanding,

$O$ and finally, that necessary autonomy of SMEs within a spectre of larger entities is to be constantly safeguarded, not the least by way of sector-related forms of institutionalization in duly recognising role and relevance of the SME sector as a whole from an overriding socio-economic perspective.

Any self-conscious, as such not to be confused with self-righteous, SME policy conceived under such auspices clearly needs - in view of legitimate claims and issues involved

- to be articulated more aggressively still, as quite an essential element within the realm of any really effective policy formulation wherever.

\section{REFERENCES}

Akokangas, P. (1998). Internationalisation and Resources. An Analysis of Processes in Nordic SMEs. Acta Wasensia, 64, Vaasa.

Aiginger, K., \& Tichy, G. (1984). Die Groeße der Kleinen. Die ueberraschenden Erfolge kleiner und mittlerer Unternehmungen in den achtziger Jahren. Vienna: Signum Verlag.

Anderson, I. (1982). Small Industry in Developing Countries. World Bank Staff (Working Papers no. 518). Retrieved on January 7, 2018 from http://documents.worldbank.org/curated/en/994781468766762001/Small-industry-in-developing-countries

Bamberger, I., \& Pleitner H.J. (Eds.). (1988). Strategische Ausrichtung kleiner und mittlerer Unternehmen, Internationales Gewerbearchiv, Sonderheft 2. Berlin-Munich-St. Gallen.

Bamberger, I. (Ed.). (1994). Product/Market Strategies of Small and Medium-sized Enterprises. Avebury: Aldershot.

Becattini, G. (1999). Flourishing small firms and the re-emergence of industrial districts. Keynote, 44th ICSB World Conference, Naples, (mimeo).

Belak, J., Kajzer, S., Mugler, J., Senjur, M., Sewing, N., \& Thommen, J.-P. (Eds.). (1997). Unternehmensentwicklung und Management unter besonderer Beruecksichtigung der Klein-und Mittelbetriebe. Zurich: Versus.

Buckley, P., \& Ghauri, P. (Eds.). (1993). The Internationalization of the Firm. London: A Reader.

Crauser, G. (1999). Enterprise Policy - Quo vadis? Challenges and Prospects for the year 2000 and beyond. Opening Address, 44th ICSB World Conference, Naples, (mimeo).

Dahiya, S.B. (1991). Theoretical Foundations of Development Planning (5 Vols., esp. Vol. 4: Sectoral and Regional Planning, Parts A and B). New Delhi. 
de Vries, B.A. (1980). Industrialization and Employment. The Role of Small and Medium-sized Manufacturing Firms. In H. Giersch (Ed.), International Economic Development and Resource Transfer. Kiel: Institute of World Economics.

Donckels, R., \& Miettinen, A. (Eds.) (1997). Entrepreneurship and SME Research On its Way to the Next Millenium. Avebury: Aldershot.

ENSR/EIM (1996, 1997, 2000). The European Observatory for SMEs, esp. Fourth to Sixth Annual Reports. Zoetermeer: EIM Business and Policy Research.

Froehlich, E., \& Pichler, J.H. (1988). Werte und Typen mittelstaendischer Unternehmer, Beitraege zur ganzheitlichen Wirtschafts- und Gesellschaftslehre (Vol. 8). Berlin: Duncker \& Humboldt.

Froehlich, E.A., Hawranek, P.M., Lettmayr, C.F., \& Pichler, J.H. (1994). Manual for Small Industrial Businesses. Project Design and Appraisal. Vienna: UNIDO General Studies Series.

Gibb, A.A. (1993). Key Factors in the Design of Policy Support for the Small and Medium Enterprise Development Process. An Overview. Entrepreneurship and Regional Development, 5, 1-24. https://doi.org/10.1080/08985629300000001

Gutersohn, A. (1977). Das Gewerbe in der freien Marktwirtschaft (3 Vols., 1954-1974, esp. Vol. 1 Das Wesen des Gewerbes und die Eigenart seiner Leistungen, 2nd ed.). Berlin-Munich-St. Gallen.

Gutersohn, A. (1981). Zur Belastbarkeit der gewerblichen Unternehmen mit gesetzlichen Vorschriften, administrativen Auflagen und mit Abgaben. In W. Kemmetmueller \& W. Sertl (Eds.), Klein-und Mittelbetriebe. Chancen, Probleme, Loesungen. Vienna.

Haahti, A.J. (1993, 1995). INTERSTRATOS. Internationalization of Strategic Orientations of European Small and Medium Enterprises. EIASM Reports 93-01 and 95-01. Brussels.

Haahti, A., Hall, G., \& Donckels, R. (Eds.). (1998). The Internationalization of SMEs. The Interstratos project. London-New York: Routledge.

Heinrich, W. (1964-67). Wirtschaftspolitik (2 Vols., 2nd ed., esp. Vol. I "Schluesselbegriffe" and Vol. II/2 "Verbandswirtschaftspolitik", "Betriebswirtschaftspolitk"). Berlin: Duncker \& Humblot.

Heinrich, W. (1964). Probleme der Klein- und Mittelbetriebe, (2nd ed.). Muenster.

Hirschman, A.O. (1958). The Strategy of Economic Development (10th ed.). New Haven-London: Yale University Press.

Institut fuer Gewerbe- und Handwerksforschung (IfG) (1992). Gewerbe und Handwerk 2000. Perspektiven und Szenarien, Schriftenreihe des Wirtschaftsfoerderungsinstitutes 216 (esp. chpts. 5 and 6). Vienna.

Institut fuer Gewerbe- und Handwerksforschung (IfG) (1994). Internationalization of Strategic Orientation in European Small Businesses. Austrian Results 1991/93. INTERSTRATOS Report, Vienna.

Institut fuer Gewerbe- und Handwerksforschung (IfG) (1998). Das burgenlaendische Gewerbe und Handwerk, Szenario 2005. Auswirkungen der EU-Osterweiterung. Vienna.

Kailer, N., \& Mugler, J. (Eds.) (1998). Entwicklung von kleinen und mittleren Unternehmen. Konzepte, Praxiserfahrungen, Perspektiven. Vienna.

Kao, R.W.Y. (1985). Small Business Management. A Strategic Emphasis. Toronto.

Kao, R.W.Y. (1985). Entrepreneurship. A Wealth-creation and Value-adding Process. New York-London.

Kemmetmueller, W., \& Sertl, W. (Eds.) (1981). Klein- und Mittelbetriebe. Chancen, Probleme. Vienna: Loesungen.

Larcon, J.-P. (Ed.) (1998). Entrepreneurship and Economic Transition in Central Europe. BostonDordrecht-London.

Lehtimaeki, A., \& Ahokangas, P. (1993). Foreign Market Orientation and International Operations of European SMEs in 1990 (Working Paper no. 7). University of Oulu. 
Levy, B. (1993). Obstacles to Developing Indigenous Small and Medium Enterprises. An Empirical Assessment. World Bank Economic Review, 7(1), 65-84. Retrieved on January 1, 2018 from http://documents.worldbank.org/curated/en/876321468740191969/Obstacles-to-developing-indigenous-small-and-medium-enterprises-an-empirical-assessment

Little, I.M.D. (1987, January). Small Manufacturing Enterprises in Developing Countries. The World Bank Economic Review, 1(2), 203-235. Retrieved on January 1, 2018 from http://documents.worldbank.org/curated/en/423351468771724270/Small-manufacturing-enterprises-in-developing-countries 1,2

Muegge, H. (1988). Entwicklungshilfe fuer kleine und mittlere Unternehmungen aus der Sicht der UNIDO. IfG Mitteilungen.

Mugler, J., \& Schmidt, K.H. (Eds.) (1995). Klein- und Mittelunternehmen in einer dynamischen Wirtschaft. Ausgewählte Schriften von Hans Jobst Pleitner. Berlin-Munich-St. Gallen: Duncker \& Humboldt.

Mugler, J. (1999). Betriebswirtschaftslehre der Klein- und Mittelbetriebe (3rd ed.). Vienna-New York.

Neck, P. (Ed.) (1977). Small Enterprise Development. Policies and Programmes. Geneva: ILO.

Pichler, J.H. (1981). Der klein- und mittelbetriebliche Sektor als Herausforderung und Anliegen weltweiter Entwicklungsstrategie In W. Kemmetmueller \& W. Sertl (Eds.), Klein- und Mittelbetriebe. Chancen, Probleme, Loesungen. Vienna.

Pichler, J.H. (1988). Gewerbe und Entwicklung. Die Rolle der Kleinbetriebe in Entwicklungsländern. IfG Mitteilungen.

Pichler, J.H. (1994). Toward a Technology Scenario 2000 and beyond. A systems-related approach geared to small business development. In H.J. Pleitner (Ed.), Small and Medium-sized Enterprises on their way into the next century. 20th International Small Business Congress (2nd ed.). St. Gallen: IGW.

Pichler, J.H. (1995). Consequences of a Larger Europe for SMEs. In Quest of SME Specific Policy Formulation. In P. Drillien (Ed.), European Yearbook (Vol. XLI). Dordrecht-Boston-London: Council of Europe.

Pichler, J.H. (1996). European Small Businesses Responding to the Larger Market. Entrepreneurial "profiles" in the context of business life cycles. In J. Mugler \& M. Nitsche (Eds.), Versicherungen, Risiko und Internationalisierung. Herausforderungen fuer Unternehmensfuehrung und Politik, Festschrift fuer H. Stremitzer. Vienna.

Pichler, J.H. (1996). SMEs at the Frontiers of Development. Assessing Success Factors for Policy Formulation. The UNIDO Manual as a Guide. An Overview. Proceedings Vol. 11, 41st ICSB World Conference. Stockholm.

Pichler, J.H. (1997). KMU als dynamischer Erfolgsfaktor im Entwicklungsprozeß. In J. Belak \& S. Kajzer (Eds.), Unternehmensentwicklung und Managment unter besonderer Beruecksichtigung der Klein- und Mittelbetriebe in den Reformlaendern. Zurich.

Pichler, J.H. (1998). SME Internationalization. Entrepreneurial profiles and patterns of strategic adjustment. Piccola Impresa, 2.

Pichler, J.H. (2015). SME-Conducive Policy Formulation under Systemic Perspective (chapter 11, pp. 169-174). In O. Nicolescu \& L. Lloyd-Reason (Eds.), Challenges, Performances and Tendencies in Organisation Management. Singapore: World Scientific.

Pichler, J.H. (Ed.) (1993). Oekonomische Konsequenzen eines EG-Beitritts Oesterreichs. Berlin: Duncker \& Humblot.

Pichler, J.H., Pleitner, H.J., \& Schmidt, K.H. (Eds.) (2000). Management in KMU. Die Fuehrung von Klein- und Mittelunternehmen (3rd ed.). Bern-Stuttgart-Vienna: Haupt.

Pleitner, H.J. (Ed.) (1989). Neue Problemperspektiven und neue Erfolgsaussichten fuer kleine und mittlere Unternehmen, Internationales Gewerbearchiv, Sonderheft 3. Berlin-Munich-St. Gallen. 
Pleitner, H.J. (Ed.) (1992). Die veraenderte Welt - Einwirkungen auf die Klein- und Mittelunternehmen, Beitraege zu den Rencontres de St-Gall. St. Gallen: IGW.

Pleitner, H.J. (Ed.) (1994). Small and Medium-sized Enterprises on their way into the next century. 2th International Small Business Congress (2nd ed.). St. Gallen: IGW.

The STRATOS Group (1990). Strategic Orientations of Small European Businesses. Avebury: Aldershot.

UNIDO (1979). Industry 2000 - New Perspectives. New York.

Van der Burg, B.I., \& Nijsen, A.F.M. (1998). How can administrative burdens of businesses be assessed? Different methods: advantages and disadvantages. Zoetermeer: EIM.

World Bank: World Development Report, Washington D. C. (annually since 1978; in the given context esp. 1987 on "Industrialization", 1991 on "The Challenge of Development", 1996 on "From Plan to Market", 2000/01 on "Attacking Poverty").

World Bank (1978). Employment and Development of Small Enterprises (Sector Policy Paper).

World Bank (1986). Industrial Restructuring (Working Paper). Washington D.C.

World Bank/CFS (1994). Eastern European Experience with Small-Scale Privatization (CFS Discussion Paper Series, no. 104). Washington D. C.

\section{Author}

\section{J. Hanns Pichler}

Prof. em. Dr. Dr. h.c. J. Hanns Pichler, M.Sc., Professor Emeritus - Vienna University of Economics and Business (Austria), Board Member and Past-President of the International Council for Small Business ICSB, Past-President of the Austrian Institute for SME Research, Member of the Editorial Board of Journal of Small Business Management, Senior Schumpeter Fellow CES Harvard.

Correspondence to: Prof. em Dr. Dr. h.c. J. Hanns Pichler, Wirtschaftsuniversität Wien, Welthandelsplatz 1, A-1020 Wien, Austria, e-mail: j.hanns.pichler@wu.ac.at

\section{Copyright and License}

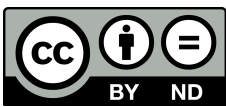

This article is published under the terms of the Creative Commons

Attribution - NoDerivs (CC BY-ND 4.0) License

http://creativecommons.org/licenses/by-nd/4.0/

\section{Published by the Centre for Strategic and International Entrepreneurship - Krakow, Poland}

Ministry of Science The copyediting and proofreading of articles in English is financed in the framework and Higher Education of contract No. 799/P-DUN/2017 by the Ministry of Science and Higher Education of 
